\section{DANDELION}

postgraduate arts journal \& research network

VOLUME 5 NUMBER I SUMMER 2014
JOHANNA SKIBSRUd currently holds a SSHRC postdoctoral fellowship at the University of Arizona and is working on a book length project on contemporary poetry. She will be joining the faculty of English at the University of Arizona in Fall of 2014, teaching modern and contemporary poetry. Her scholarly reviews and articles have been published in Mosaic, The Brock Review, antiTHESIS, Hyphen, The Volta, and Reviews in Cultural Theory. She is also the author of two books of poetry, a collection of short stories, and a novel. A second novel, Quartet for the End of Time (Penguin/William Heinemann/Norton) will appear in September 2014.

jskibsrud@email.arizona.edu

Article

\title{
'A History of the Present': Knowledge as Violence in Cormac McCarthy's Blood Meridian
}

\author{
Johanna Skibsrud
}

'IT MAKES NO DIFFERENCE WHAT MEN THINK OF WAR,' says the Judge in Cormac McCarthy's Blood Meridian. 'War endures. As well ask men what they think of stone.' It is, however, through 'thinking of stone' that we may come to know something of war. Blood Meridian, this paper argues, offers readers a way of thinking past the limited framework of human experience, towards the more enduring power structures of nature. Though based on historical events, the novel effects what Foucault, in Discipline and Punish, calls a 'history of the present $^{2}$ - a history, that is, that does not merely report the past, but offers an interpretative account of the 'power configurations persisting in the present'. ${ }^{3}$ The constant underscoring within the novel of a greater and ungovernable force than that of human reason and power points ultimately to the short-sightedness of assumed proprietorship of the land, and indicates that such an assumption must necessarily pass out of favour - just as assumed proprietorship over human life has done. What we are confronted with, therefore, in Blood Meridian is not (or not only) a nihilistic argument of the ungovernableness or inherent cruelty and violence of people, but a question of what can and should be governable, even knowable, by human beings.

In a 1948 essay, 'The Land Ethic', American ecologist Aldo Leopold wrote: 'There is as yet no ethic dealing with man's relation to land and to the animals and plants which grow upon it. Land, like Odysseus's slave-girls, is still 
property. ${ }^{4}$ In Blood Meridian the attitude towards both human beings and the land could be described as Leopold described human-land relations: 'strictly economic, entailing privileges but not obligations.' ${ }^{5}$ But where Leopold detected 'an embryo of affirmation ${ }^{6}$ in the conservation movements begun in the mid-twentieth century in the United States, Blood Meridian describes an inescapable power structure from which (more in keeping with Foucault's notions of power and repression) there can be 'no hope of escape." As in Foucault's thinking, this is the result, not of dead-ended 'progress', but of the conceptualization of a radically different understanding of the term. For McCarthy in Blood Meridian - as for Foucault - the question of a time-bound and unidirectional 'progress' is obsolete. 'I don't say that humanity doesn't progress,' writes Foucault. 'I say that it is a bad method to pose the problem as: "How is it that we have progressed?" The problem is: how do things happen? And what happens now is not necessarily better or more advanced, or better understood, than what happened in the past. ${ }^{8}$ Blood Meridian poses this same question to the reader and, in doing so, moves beyond the simple insistence upon a transcendental 'essence' of the human (dominant at least since the Enlightenment), towards the larger question of the way 'things happen' at all. Ultimately, therefore, the novel moves past a static conception of both human and nature; it proposes a never-ending process of change without teleology or progress. History in Blood Meridian is - like the present - presented merely as a collection of events.

In reminding his contemporaries of the short-sightedness of their present ecological and economic endeavours, Leopold suggests a similar method of questioning and understanding the world from a holistic point of view, rather than from any one particular vantage point in time. 'Just as a deer herd lives in fear of its wolves,' he says, 'so does a mountain live in mortal fear of its deer. And perhaps with better cause, for while a buck pulled down by wolves can be replaced in two or three years, a range pulled down by too many deer may fail of replacement in as many decades'. ${ }^{9}$ It is because we fail, again and again, Leopold argues, to 'think like a mountain' (like, or 'of' stone) that 'we have dustbowls, and rivers washing the future into the sea.'.

Blood Meridian 'thinks like a mountain'. Time - and along with it, any notion of a time-bound 'progress' - are, like dust, 'dispersed and lost'. ${ }^{11}$ Characters wander patternlessly across the desert, impelled only by the threat, or the lure, of violence. Moral judgment of violence is also, and equally, 'dispersed and lost' - not only through the dissolution of any regularly accepted timescale, but also through the parodic portrayal of the superhuman character of the Judge. The Judge's zeal to achieve power through knowledge caricatures the inefficacy and inadequacy of the Enlightenment-influenced notion - still persistent in our era - that through knowledge and reason human beings can, and will, attain and effect absolute power. 'Whatever in creation exists without my knowledge exists without my consent, ${ }^{, 12}$ says the Judge in explanation of the endless documentation he makes of the world around him.

These anonymous creatures [...] may seem little or nothing in the world. Yet the smallest crumb can devour us. Any smallest thing beneath yon rock out of men's knowing. Only nature can enslave man and only when the existence of each last entity is routed out and made to stand naked before him will he be properly suzerain of the earth. ${ }^{13}$

The fear of nature so blatantly expressed within these lines underscores the ultimate power imbalance between the Judge and what he hopes one day to understand and control. As fearsomely powerful and at times supernatural as 
the Judge may therefore appear, these lines point to his vulnerability, and prove that he too - like everything and everyone else - is ultimately bound by, and subservient to, nature. When asked by Toadvine, for example, why he chooses the word 'suzerain' over the more familiar 'keeper', the Judge explains that a suzerain is 'a special kind of keeper. A suzerain rules even when there are other rulers. His authority countermands local judgments. ${ }^{14}$ But the power the Judge wields is doomed also to partiality, despotism, and, ultimately, to failure - like all human power, as the novel seems to suggest, based as it is only on partial knowledge of what he wishes to control. Even the Judge's final act - the murder of the novel's protagonist, 'the kid', in the outhouse of a bordello - falls short of its goal. Just before he murders him, the Judge greets the kid by saying: 'I recognized you when I first saw you and yet you were a disappointment to me. Then and now. Even so at the last I find you here with me. ${ }^{15}$ But the kid objects, 'I aint with you. ${ }^{16} \mathrm{He}$ does not, in other words, understand himself to fall under the Judge's power or domain. The kid's resistance remains vital even when, a moment later, he is 'gather[ed]' into the Judge's arms - the Judge almost literally subsuming him. Even the Judge is forced to admit it: that the kid has 'held back' what others had given so freely - each, the Judge says, 'except one', having '[emptied] his heart into the common. ${ }^{17}$ 'You were a witness against yourself,' the Judge accuses the kid. 'You sat in judgment on your own deeds. You put your own allowances before the judgments of history and you broke with the body of which you were pledged a part and poisoned it in all its enterprises. ${ }^{18}$ Although the kid's opposition to the Judge might, on the surface, look like an opposition to the violence the Judge perpetrates and preaches, this cannot be considered the case. What the kid has 'held back' from the Judge is not his willingness to take part in the Judge's violence, or to accept the ideology that supports it, but his own perspective and judgment of that violent ideology. The kid remains aloof, autonomous - eluding, at least for the duration of the novel, the Judge's effort to have nothing permitted 'save by [his] dispensation'. ${ }^{19}$ The kid's autonomy is both more total and more complex than a simple Enlightenment-era notion of self-awareness and self-reliance, however. $\mathrm{He}$ is reflexively self-aware - he sits in 'judgment' of his own deeds - but he does so, apparently, without approaching the category of the universal. The kid's 'judgments' are entirely his own; they do not blend into 'the common' or the 'judgments of history'. Indeed, they are not even made accessible to the reader. Though the reader follows the novel's course of action almost entirely through the kid's eyes, she is never properly able to discern what the kid actually thinks, or how he interprets events. By excluding himself in this way from any 'common' story, the kid places the very existence of the universal under question.

John Rothfork argues that the message within McCarthy's work is recognizably one of 'pragmatism and postmodernism'. ${ }^{20}$ Certainly, if we are to think of postmodernism as "the death of $[\ldots]$ "metanarratives" whose secretly terroristic function was to ground and legitimate the illusion of a "universal' human history, ${ }^{21}$ we can see the manner in which Blood Meridian subscribes to and reflects such classification. The novel attempts to move past the assumption (originating in the Enlightenment, and more recently reimagined by the 'modern' era) of 'scientific domination' over nature - with its accompanying promise of 'freedom from scarcity, want, and the arbitrariness of natural calamity $[\ldots]$ as well as from the dark side of our human natures' ${ }^{22}$ Not long into the twentieth century, it became obvious that human culture was falling painfully short of the optimistic vision for the future 'modern' science 
and thinking had promised. 'The twentieth century -' writes David Harvey in The Condition of Postmodernity,

with its death camps and death squads, its militarism and two world wars, its threat of nuclear annihilation and its experience of Hiroshima and Nagasaki - has certainly shattered this optimism. Worse still, the suspicion lurks that the Enlightenment project was doomed to turn against itself and transform the quest for human emancipation into a system of universal oppression in the name of human liberation. ${ }^{23}$

Blood Meridian operates outside any 'modern', transcendental, or totalizing power - emphasizing, instead, what Foucault refers to as micro-powers. 'For Foucault,' writes David Couzens Hoy,

\begin{abstract}
neither comprehending the world nor changing it depends on grasping (in either the theoretical or the practical sense) the totality, since the concept of totality is not applicable to his understanding of power as an open-ended network or grid. Rather, his 'micro-physics' of power depends on comprehending power by first studying the everyday practices where individuals continually experience micro-powers, the particular confrontations with and resistances to impositions of power. ${ }^{24}$
\end{abstract}

Nature's extreme unwillingness to submit itself ultimately to human domination (as we strive to achieve, in the words of Leopold, 'safety, prosperity, comfort, long life, and dullness' ${ }^{25}$ is testament to a similar 'micro-physics' at work in nature. A measure of success in achieving the safety - as well as the dullness - that we are supposedly looking for is, says Leopold, 'well enough', but, he goes on to say, we must also remember that 'too much safety seems to yield only danger in the long run [...] In wildness is the salvation of the world. Perhaps this is the hidden meaning in the howl of the wolf, long known among mountains, but seldom perceived among men. ${ }^{26}$ But even 'wildness' in this sense is something projected - gridded onto the landscape. The inherent difficulty of referring to 'wildness' without setting up an all too familiar dichotomy, which actually serves to reinforce the notion of human domination over the landscape, is presented to us here. McCarthy's strategy in Blood Meridian is a Foucauldian one. He avoids reimagining a 'hidden meaning' or essence to wildness by presenting a 'micro-physics' of power, which - in acting as an 'open-ended network or grid'; in refusing totality and thus any ultimate meaning (hidden or unhidden) - works to enact rather than simply represent 'wildness'.

If the notion of achieving ultimate dominion over human beings is now theoretically - if not practicably - untenable, the notion of ultimate dominion over the land is as yet not. It is in this way that Blood Meridian's account of cruelties perpetrated by human beings can be read as a 'history of the present'; in other words, as representative of a power structure, which - still in place today - allows for the continued abuse and destruction of our environment (therefore, of course, also of ourselves). Through its detailed descriptions of the atrocities and inanities of a specific and now distant period of time, McCarthy forces us to bear witness to the tortured body, and thereby confront the realities of our culture and its systems of violence.

In Discipline and Punish, when Foucault discusses the abolition of public executions in France at the beginning of the nineteenth century, he notes a resulting shift in the idea of the public and the private body. 'It was,' he 
writes, 'the end of a certain kind of tragedy; comedy began, with shadow play, faceless voices, impalpable entities. The apparatus of punitive justice must now bite into the bodiless reality'. ${ }^{27}$ Blood Meridian resurrects this 'certain kind' of old-world tragedy. We are not permitted to deal in mere voices and shadows, but forced, instead, to witness - and therefore participate in - the torture and oppression of the physical body.

Foucault argues that over the past 200-plus years, Western penal systems have "taken to judging something other than crimes, namely, the "soul" of the criminal'. ${ }^{28}$ We have moved away from establishing the "truth of a crime ${ }^{29}$ from, that is, corporeal judgment and punishment - towards a 'quite different question of truth' $;^{30}$ questions regarding an alleged crime are no longer, in other words, particular ones of verification and sentencing, but rather of the nature of crime itself: 'What is this act, what is this act of violence of this murder? To what field of reality does it belong?. ${ }^{31}$ This presumption to know and to judge the answer to such questions is precisely what we see manifest in the character of the Judge in Blood Meridian. The delusional grandeur of his vision of domination parodies the Western approach to reason and power: 'The Judge placed his hands on the ground. This is my claim, he said. And yet everywhere upon it are pockets of autonomous life. Autonomous. In order for it to be mine nothing must be permitted to occur upon it save by my dispensation. ${ }^{32}$ In the last decade or so this approach has been evident, almost in a caricatured form, in the 'war on terror', and an increase in 'precision' thinking in warfare (or at least an increase in the technological developments, which allow this sort of thinking to be more precisely carried out). Surveillance and the targeting of individual terrorists, indefinite detention without habeas corpus, and drone warfare - all might be considered in terms of the Enlightenment notion that, through the achievement of more and more 'scientific' information, we might eventually eradicate all human suffering - as well as 'the dark side of our human natures. ${ }^{33}$ The shift Foucault describes (from the judgment of the deed and the body to the judgment of the crime and the soul) tends, of course, towards further abstraction - shifting the question away from what is, and from what can be known, to what cannot - while still presuming to judge that (sur-)reality. At the same time, then, that an increased emphasis is placed on moving away from 'mystery and fear' - as man 'sets himself the task of singling out the thread of order" ${ }^{34}$ in the world - he is ultimately returned to 'mystery and fear', because he has set himself such an impossible task. 'No man,' as Toadvine says, 'can acquaint himself with everything on earth' ${ }^{35}$ In his vain effort to do so, he positions himself within an impossible - and possibly dangerous - situation: not knowing what he assumes he has given himself the jurisdiction to know, and therefore assumes he should and does know. He is confronted with an impasse, or, as Derrida writes, with 'the aporia: the difficulty of the impracticable, here the impossible passage, the refused, denied, or prohibited passage, indeed the nonpassage'. ${ }^{36}$ This nonpassage, according to Derrida, occurs when what should appear to 'block our way' gives way to the impossible, where

we are exposed, absolutely without protection, without problem [...] $[\mathrm{N}]$ ot that, alas or fortunately, the solutions have been given, but because one could no longer even find a problem that would constitute itself and that one would keep in front of oneself, as a presentable object or project, as a protective representative or a prosthetic substitute, as some kind of border still to cross or behind which to protect oneself. $^{37}$ 
We are, in Foucault's analysis of the contemporary judicial experience, also left without 'a presentable object ${ }^{38}$ - a deed, a body - to judge.

This phenomenon, of judging and treating a body where there is no body, which Foucault articulates and explores by way of the legal system, has in recent years been further literalized in the realm of medicine. New developments have eliminated the need in many cases for human medical practitioners, and scientists claim that very soon the body may be assessed, judged, and treated, without ever having to encounter another body. ${ }^{39}$ 'We continue to invent devices that "translate us into information", says Luke Mitchell, but, he warns, 'we sometimes forget that such measurement itself was an invention', ${ }^{40}$ or that, as we increasingly become able to 'transport reality into a virtual realm $[\ldots]$ that ideas, in their Platonic perfection, are considerably more amenable to the strictures of rational analysis than the raw grit of nature ${ }^{41}$ The more we expand our notion of what is, or may be, within our range and ability to understand, and 'therefore control', the more we employ a 'godlike ability to translate material qualities into abstract - and therefore controllable - quantities, ${ }^{42}$ the more literal the aporias we confront may become.

And we are certainly expanding this notion quickly. When William Harvey, for example, first reported his discovery of the manner in which blood flowed in the human body, he was sharply admonished: 'Truly, Harvey, you are pursuing a fact which cannot be investigated, a thing which is incalculable, inexplicable, unknowable..$^{43}$ As the territory of the 'incalculable, inexplicable, unknowable' is increasingly conquered by rationalism, science, technology, and medicine, does 'mystery and fear' actually lessen or do we translate our fear into other terms? 'In our culture,' declares Mitchell,

[the] will to dematerialize remains, perhaps somewhat ironically, unarticulated and inchoate. This may explain our strange, indeed neurotic, sense that the needs of the 'system' - whether it is the system of governance or the system of markets or the system of technological innovation - are now more important than the needs of the individuals such systems assumed to serve. ${ }^{44}$

Paradoxically, it is, perhaps, our fear of disembodiment - of suffering, and ultimately of death - that drives us towards the greater and greater abstraction of human life.

If we are consistently impelled in the direction of 'dematerialization', with what will we at last be confronted but an ultimate impasse: a complete moral and cultural aporia? Blood Meridian is constructed on the idea of just such a moral and cultural impasse. The condition of 'pathlessness' in the novel is exemplified by the patternless wanderings of the characters. 'De dónde viene? Called the strangers. A dónde va? Called the judge. ${ }^{45}$ But no destination is ever finally sought, and therefore finally reached, in the novel. Each path dissolves into different, contradictory, directions - often forcing the party to retrace steps that have already been taken. 'And so these parties divided upon that midnight plain, each passing back the way the other had come, pursuing as all travelers must inversions without end upon other men's journeys. ${ }^{46}$ It is the land that asserts dominion over the fleeting desires and destinations of men: 'For the earth is a globe in the void and truth there's no up or down to it. ${ }^{47}$ Though human power - its implementation and abuse - is also depicted in insistent detail throughout the novel, it is the landscape that prevails as the dominant force. The men, their cities, and their deeds, only disappear again 
and again within the 'hallucinatory void"48 of the desert landscape - just as they do for the kid and Sproule on the morning they witness a desert mirage. Having 'slept among the rocks face up like dead men', they rise to find that 'there was no city and no trees and no lake only a barren dusty plain'. 49

This supremacy of nature in Blood Meridian (which, again and again, both literally and figuratively, dissolves the fantasies of power briefly entertained by people) is further emphasized by the repeated reference to the 'ruins of an older culture ${ }^{50}$ in which the American party often house themselves. Just prior to the American massacre of an Apache village, for example, the Judge records the ancient rock paintings that had been located in the desert cisterns - testament to a civilization whose illustrations 'of men and animals and of the chase [...] were constructions of such singular vision as to justify every fear of man and the things that were in him'. ${ }^{51}$ Shortly after the Aboriginal village has been destroyed by the Judge and his men, the omniscient narrative voice reflects:

\begin{abstract}
In the days to come the frail black rebuses of blood in those sands would crack and break and drift away so that in the circuit of few suns all trace of the destruction of these people would be erased. The desert wind would salt their ruins and there would be nothing, not ghost nor scribe, to tell to any pilgrim in his passing how it was that people had lived in this place and in this place died. ${ }^{52}$
\end{abstract}

This same sense of both the inescapability and the transience of ascendancies and repressions is evident in Leopold's 'The Quality of the Landscape', in which he writes:

\begin{abstract}
We forest officers, who acquiesced in the extinguishment of the bear, knew a local rancher who had plowed up a dagger engraved with the name of one of Coronado's captains. We spoke harshly of the Spaniards who, in their zeal for gold and converts, had needlessly extinguished the native Indians. It did not occur to us that we, too, were the captains of an invasion too sure of its own righteousness. ${ }^{53}$
\end{abstract}

In our continued attempt to exclude ourselves from the uses and abuses of power - by redefining our method of judgment and punishment in order for it to appear as though we are not a part of the system that punishes the body, but instead involved in a more righteous quest 'to obtain a cure ${ }^{, 54}$ for the 'soul' - we effect a double oversight. First, in declaring for ourselves such an exemption, we assume a degree of power over the natural world that is ultimately insupportable. Second, in assuming this excessive and insupportable degree of power - to know and govern 'everything on this earth" ${ }^{, 5}$ - we actually limit our intellectual and moral capacity to know and to judge that which falls within the necessarily circumscribed ambit of our current knowledge and accepted moral code. 'Perhaps,' suggests Foucault in Discipline and Punish,

\begin{abstract}
we should abandon a whole tradition that allows us to imagine that knowledge can exist only where the power relations are suspended and that knowledge can develop only outside its injunctions, its demands and its interests [...] We should admit rather that power produces knowledge (and not simply by encouraging it because it serves power or by applying it because it is useful); that power and knowledge directly imply one another. ${ }^{56}$
\end{abstract}

If we are to abandon a tradition that imagines we can exempt ourselves from the structures of power, as Foucault suggests, then certainly we must 
abandon the notion that we can exempt ourselves from that greatest power structure of all - that of nature. But to further imagine that a return to nature (or a recognition of nature at the heart of human nature) requires an acceptance of the Judge's suggestion that we might as well raise our children by setting them 'in a pit with wild dogs' and have them 'run naked in the desert' ${ }^{57}$ is far too simplistic, and merely returns us to the old dichotomies. Blood Meridian works precisely to disrupt the dichotomy of man versus nature - as well as the idea of any 'hidden meaning' (even one at odds with current moral codes) at the heart of human nature.

Foucault argues that 'the violence-ideology opposition, the metaphor of property, the model of contract and conquest ${ }^{57}$ must be abandoned - that the 'soul' the contemporary judicial and penal systems purport to judge and punish no longer be considered an 'illusion', but, instead, a reality born out of 'methods of punishment, supervision and constraint [...] the element in which are articulated the effects of a certain type of power. ${ }^{58}$ It is not, therefore, that we must deny or accept anything intrinsic to our 'nature', but that we must understand ourselves to be, at all levels, created by surrounding powerstructures. Judgment is not only the application of power, but the product of power - itself something that has been created and employed within an 'openended network or grid', ${ }^{59}$ which, while producing events in a continuous process of flux and relation, resists any concept of totality or meaning. In opposition to this open and generative process, the blind assumption of power so grossly parodied in Blood Meridian by the Judge - a desire to be 'properly suzerain of the earth ${ }^{60}$ - destroys everything it touches - even, in the end, the novel's protagonist, and with him any possibility of further developing the story.

In his essay 'The Land Ethic', Leopold remarks:

In human history, we have learned (I hope) that the conqueror role is eventually self-defeating. Why? Because it is implicit in such a role that the conqueror knows, ex cathedra, just what makes the community clock tick, and just what and who is valuable, and what and who is worthless, in community life. It always turns out that he knows neither, and this is why his conquests eventually defeat themselves. ${ }^{61}$

It is by being too sure of our own 'righteousness ${ }^{, 62}$ that, according to Leopold, we reproduce a cycle of domination and oppression - and nowhere is this clearer than in our relationship to the earth.

This wisdom is also at the heart of Blood Meridian. Where our knowledge is (necessarily) flawed, so too - the novel suggests - is the power that we wield. With McCarthy, however, there is no suggestion of any possible 'salvation in the wild'. ${ }^{63}$ Blood Meridian 'thinks like a mountain', but it does so by subverting the empathy Leopold asserts as necessary in order to understand, and live sustainably, alongside the earth. Where Leopold's use of the phrase, that is, still implies an ability to penetrate, control, and ultimately anthropomorphize what remains beyond the bounds of human experience and knowledge, McCarthy's novel works against the idea of any static or totalizable (therefore transferrable) meaning outside of direct experience. There is no alternative to violence in Blood Meridian, nothing to which to 'return'. Like everything else, violence does not exist for McCarthy as a fixed or knowable category; it is, instead, continuously created anew by the shifting "'microphysics" of power', which make up our 'everyday practices'. It is always specific, embodied; it therefore must be confronted as such. Just like our contemporary world, the novel fails to offer any transcendental categories to which we might 
retreat. Neither does it offer any easy either/or scenario where violence can simply be discarded for peace, injustice for justice, or progress for nature. In other words, the novel does not propose an abandonment of - or an alternative to - modern scientific progress and reason, but instead a more appropriate way of exercising it: a way that resists rationalist reductionism and retains within it the capacity to recognize, and therefore work towards balancing, the contradictions with which our world will continue to abound.

University of Arizona

\section{Notes}

Cormac McCarthy, Blood Meridian (New York: Vintage International, 1985), p. 248. Michel Foucault, Power/Knowledge (New York: Pantheon Books, 1980), p. 31. Foucault: A Critical Reader ed. by David Couzens Hoy (New York: Basil Blackwell, 1986), p. 138.

Aldo Leopold, A Sand County Almanac (Oxford: Oxford University Press, 1966), p. 238.

Leopold, A Sand County Almanac, p. 238.

Leopold, A Sand County Almanac, p. 239.

Sheldon S. Wolin, 'On the Theory and Practice of Power', in After Foucault: Humanistic Knowledge, Postmodern Challenges, ed. by Jonathan Arac (New Brunswick: Rutgers University Press, 1991), p. 186.

Foucault, Power/Knowledge, p. 50.

Leopold, A Sand County Almanac, p. 140.

Leopold, A Sand County Almanac, p. 140.

McCarthy, Blood Meridian, p. 44.

McCarthy, Blood Meridian, p. 198.

McCarthy, Blood Meridian, p. 198.

McCarthy, Blood Meridian, p. 199.

McCarthy, Blood Meridian, p. 328.

McCarthy, Blood Meridian, p. 328.

McCarthy, Blood Meridian, p. 307.

McCarthy, Blood Meridian, p. 307.

McCarthy, Blood Meridian, p. 199.

John Rothfork, 'Cormac McCarthy as Pragmatist', Critique: Studies in Contemporary Fiction, 47.2 (2006), 201-214 (p. 202).

David Harvey, The Condition of Postmodernity (Cambridge, MA: Basil Blackwell, 1989), p. 9.

Harvey, The Condition of Postmodernity, p. 12.

Harvey, The Condition of Postmodernity, p. 13.

Hoy, Foucault: A Critical Reader, p. 143.

Leopold, A Sand County Almanac, p. 141.

Leopold, A Sand County Almanac, p. 141.

Michel Foucault, Discipline and Punish, trans. by Alan Sheridan (New York: Second

Vintage Books Edition, 1995), p. 17.

Foucault, Discipline and Punish, p. 19.

Foucault, Discipline and Punish, p. 19.

Foucault, Discipline and Punish, p. 19.

Foucault, Discipline and Punish, p. 19.

McCarthy, Blood Meridian, p. 199.

Harvey, The Condition of Postmodernity, p. 12.

McCarthy, Blood Meridian, p. 199.

McCarthy, Blood Meridian, p. 199.

Jacques Derrida, Aporias, trans. by Thomas DuToit (Stanford: Stanford University

Press, 1993), p. 8.

Derrida, Aporias, p. 12

Derrida, Aporias, p. 12. 


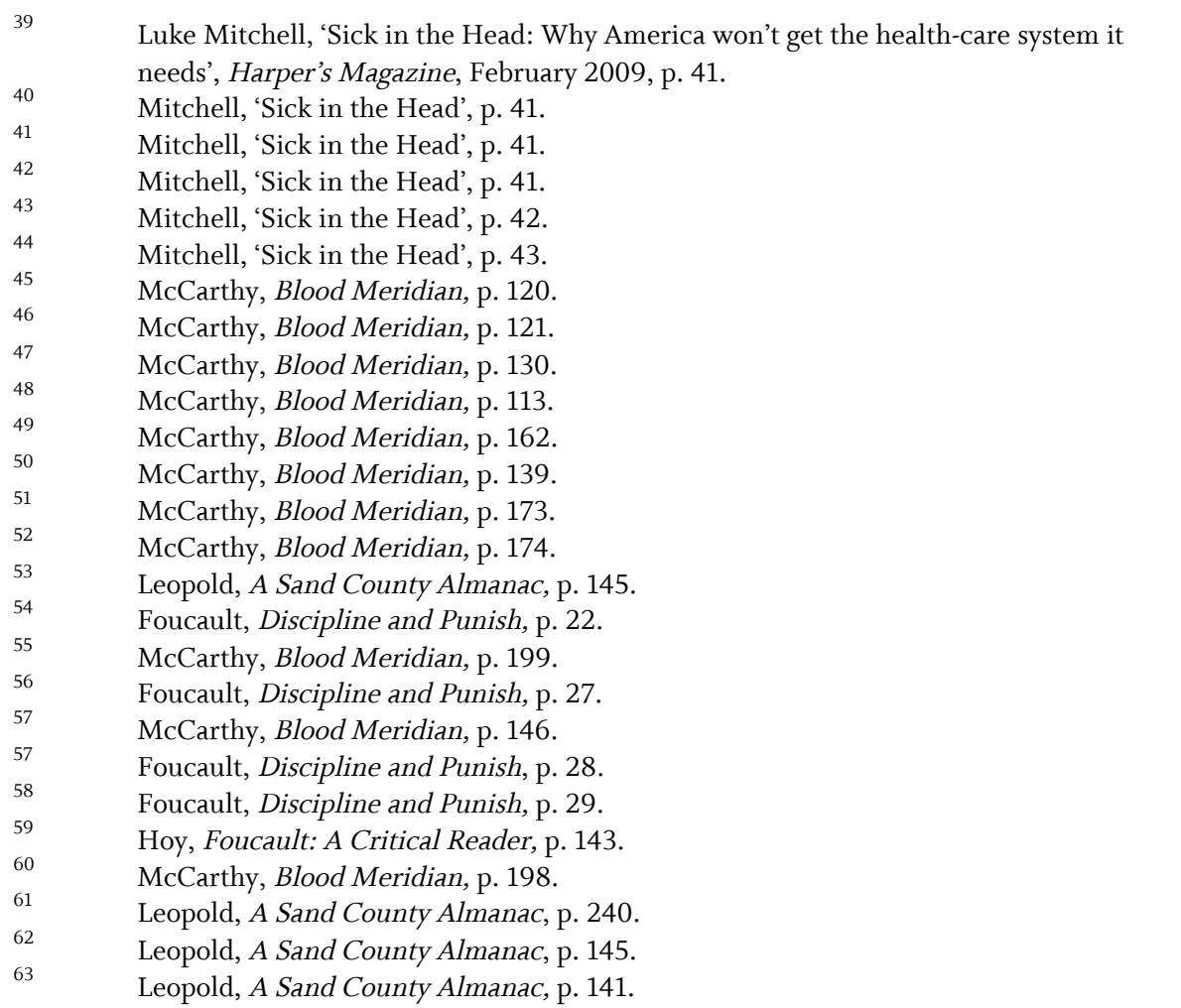

\section{Works Cited}

Derrida, Jacques, Aporias, trans. by Thomas DuToit (Stanford: Stanford University Press, 1993)

Foucault, Michel, Discipline and Punish, trans. by Alan Sheridan (New York: Second Vintage Books Edition, 1995)

Power/Knowledge, ed. by Colin Gordon (New York: Pantheon Books, 1980)

Harvey, David, The Condition of Postmodernity (Cambridge, MA: Basil Blackwell, 1989)

Hoy, David Couzens, ed., Foucault: A Critical Reader (New York: Basil Blackwell, 1986)

Leopold, Aldo, A Sand County Almanac (Oxford: Oxford University Press, 1996)

McCarthy, Cormac, Blood Meridian (New York: Vintage International, 1985)

Mitchell, Luke, 'Sick in the Head: Why America won't get the health-care system it needs', Harper’s Magazine, February 2009, p. 33-44

Rothfork, John, 'Cormac McCarthy as Pragmatist', Critique: Studies in Contemporary Fiction, 47.2 (2006), 201-214

Wolin, Sheldon S., 'On the Theory and Practice of Power', in Jonathan Arac, ed., After Foucault: Humanistic Knowledge, Postmodern Challenges (New Brunswick: Rutgers University Press, 1991) 